\title{
WestVirginiaUniversity
}

THE RESEARCH REPOSITORY @ WVU

West Virginia Agricultural and Forestry Experiment

Davis College of Agriculture, Natural Resources

Station Bulletins

And Design

$1-1-1928$

\section{Comparative Tests of Certain Feeds in Rations for Pigs}

E. A. Livesay

E. C. Stillwell

Follow this and additional works at: https://researchrepository.wvu.edu/ wv_agricultural_and_forestry_experiment_station_bulletins

\section{Digital Commons Citation}

Livesay, E. A. and Stillwell, E. C., "Comparative Tests of Certain Feeds in Rations for Pigs" (1928). West Virginia Agricultural and

Forestry Experiment Station Bulletins. 213.

https://researchrepository.wvu.edu/wv_agricultural_and_forestry_experiment_station_bulletins/213

This Bulletin is brought to you for free and open access by the Davis College of Agriculture, Natural Resources And Design at The Research Repository @ WVU. It has been accepted for inclusion in West Virginia Agricultural and Forestry Experiment Station Bulletins by an authorized administrator of

The Research Repository @ WVU. For more information, please contact ian.harmon@mail.wvu.edu. 
EVANGDALE LIBRARY WEST VRGINIA UNVERSITY 
Restricted

\section{Circulation Only}

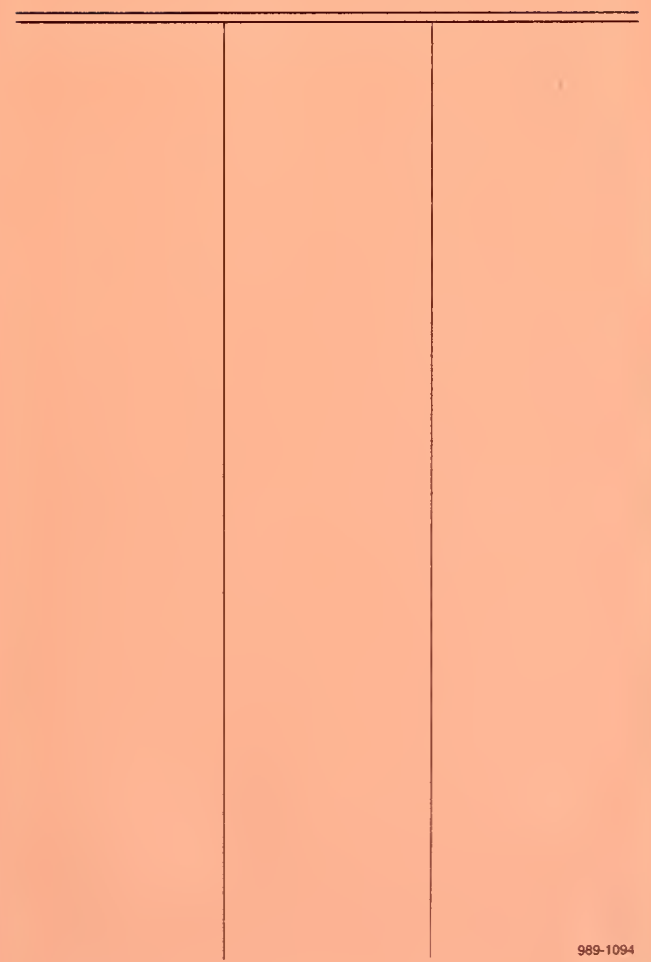





\section{Angricultural Tixperiment Station}

College of Agriculture, West Virginia University

N. J. Giddings, Acting Director

Morgantown

\section{Comparative Tests of Certain Feeds in Rations for Pigs}

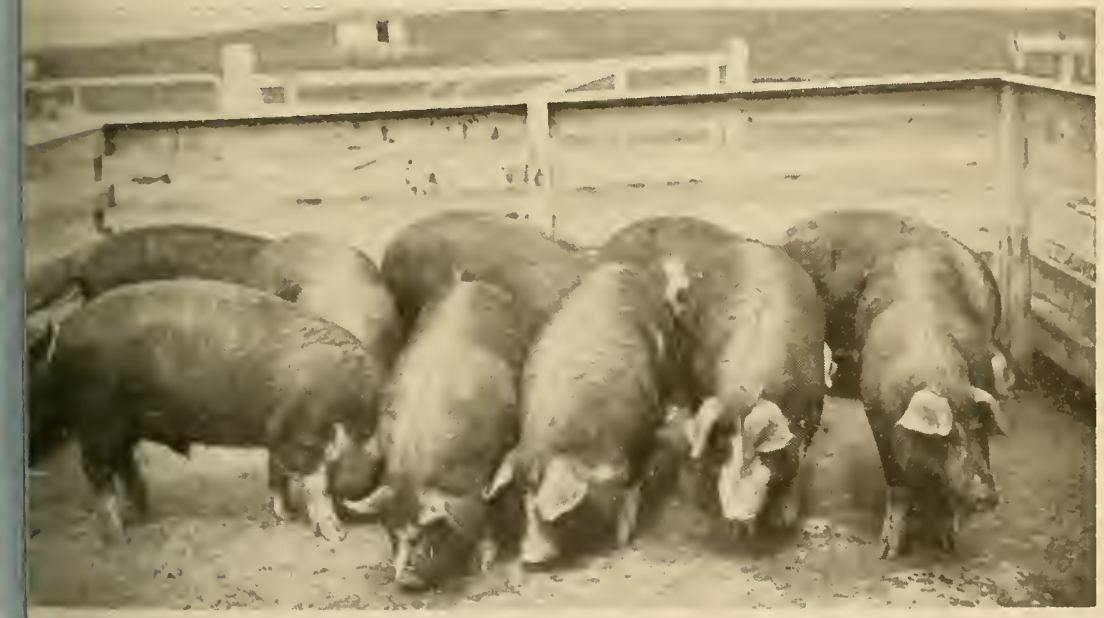

By

E. A. LIVESAY and E. C. STILLWELL

Publications of this Station will be mailed free to any citizen of West Virginia on written application. Address Director of the West Virginia Agricultural Experient Station, Morgantown, West Virginia. 
In recent years, many requests have been received in regard $t$ the value of buckwheat middlings, and in order to answer such ir quiries, the experimental work herein reported was started. The feec ing trials with buckwheat middlings were run on similar pigs, covere the same number of days, etc., as the yellow and white corn trials.

While the production of buckwheat in West Virginia is not ver great, it is of sufficient importance in several counties to demand mor information as to the feeding value of its by-products for hogs an cattle as compared with other concentrates. The more mountainor sections of the state, as shown in Figure 1, produce buckwheat to considerable extent. According to the last census report, Presto county leads all other counties of the state; its annual productio being approximately 200,000 bushels.

The reports of feeding trials with tankage and fish meal, and the fermentation of the carbohydrate feeds with yeast are considere as preliminary, but have been included in this publication since tl work was conducted in conjunction with the comparisons of yellow an white corn, and of wheat middlings and buckwheat middlings.

\section{REVIEW OF LITERATURE*}

In 1920, Steenbock and Boutwell (8), in their work with ra discovered a striking difference in the vitamin A content of yellow ar white corn. Following Steenbock's discovery, Morrison, Bohstec and Steenbock conducted a feeding trial with pigs to determine t] relative values of white and yellow corn in producing pork. Russe and Morrison (6) have reported that these investigators found yello corn to be superior to white corn, when fed with tankage since 16 pe cent more white corn than yellow corn was required to produce 1 pounds gain. Russell and Morrison ( $r$ ) have also reported the san results for yellow and white corn in another feeding trial conducted 1 Morrison, Fargo, and Bohstedt. These investigators found yellow co: to be superior to white corn, when fed with tankage, as well as wh. supplemented with skim-milk. The pigs used in this work weigh. from 50 to 60 pounds at the beginning of the trials, and were carri. to 200 pounds. When tankage was used as a supplement to white al. yellow corn (both lots self-fed), the yellow corn lot made an avera: daily gain of 1.06 pounds and required 447 pounds of feed per 1 pounds gain, while the white corn made 0.63 pounds daily gain as required 554 pounds of feed per 100 pounds gain. The lots receivir; skim-milk as a supplement to corn also showed the inferiority of whj;

*All literature cited with respect to hogs refers to dry lot feeding. 
orn. The white corn and skim-milk lot made practically as rapid ;ains as the lot fed yellow corn and skim-milk for a time, but finally learly all the pigs died from what seemed to be pneumonia.

The Illinois Station (4) has reported that nine out of ten fiftysound pigs died on a ration of white corn and tankage before reaching narkctable age, while another lot on the same ration plus a small imount of cod-liver oil grew normally to a weight of 275 pounds.

A preliminary report of the Nebraska Station (9) showed yellow :orn to have a feeding value slightly superior to that of white corn, vhen both were fed to pigs weighing from 67 to 114 pounds over an werage period of 88 days. There were no indications of rickets dereloping in the lots fed on white corn, which, according to the report, ras probably due to the fact that the pigs were fairly large when they were started on the two corn rations.

Lamb and Evvard (2) have reported that when a brood sow and ler litter were fed upon a ration composed of white corn, oats, linseed oil meal, and a salt mixture containing lime, the pigs either died, r made little growth until vitamin A was added to the ration. These nvestigators worked with small numbers, and with pigs a part of which were heavily infested with ascari (round worm).

The same authors have also reported the results obtained in fatrening pigs by feeding white corn as compared to yellow corn, in a ration similar to the one just mentioned. Very little difference was found between yellow and white corn for pigs of the weights usedapproximately 130 pounds at the start.

Robinson (5) of the Ohio Station found buckwheat middlings to be inferior to tankage, when fed as a supplement.

\section{EXPERIMENTAL METHODS \\ Pigs Used}

The purebred pigs used in these feeding trials, composed of DurocJersey, Poland-China, and Berkshire breeding, were divided into lots of 10 , each year, as nearly equal as possible in regard to breed, size, and thrift. The pigs were approximately 14 weeks of age at the start of the trials, with an average weight of 70 to 80 pounds each. All sows and their litters were fed and handled in a similar manner, previous to the start of the feeding trials. In Lots I and III (1923), it was discovered that one pig in each lot was not eating and was falling off in flesh. These pigs were removed from the lots soon after the trial started. Upon inspection, the pig in Lot III was found to be blind, but there was no visible external or indicated internal condition of the pig in Lot I to warrant its going off feed. 


\section{Equipment}

All lots were fed in metal troughs on concrete floors. The sleeping pens as well as the outside runways were also concrete floored, so that the pigs were never off concrete during the test periods. Sleeping quarters were kept well bedded at all times. The pens and runways for all lots were of equal size (pens inside, 8 by 24 feet and runways 12 by 24), and all lots were about equally exposed to sunshine.

\section{Feeds and How Fed}

Table 1 gives the chemical analyses of the feeds used, and also the analyses of similar feeds, as taken from Henry and Morrison's tables in their book entitled "Feeds and Feeding." The greatest variation in the analyses of any one of the feeds' used over the three years occurred in the case of buckwheat middlings. The crude protein of this feed varied from 22 to 32 percent. This variation was due to the lack of standardization in the milling of buckwheat flour, and not to adulterations. All feeds were of good quality. The yeast fed in 1924 and 1925 was the ordinary granular form.

TABLE 1.-Chemical Analyses of Feeds Used Compared with Analyses of Similar Feeds as Given by Henry and Morrison in "Feeds and Feeding."

\begin{tabular}{|c|c|c|c|c|c|c|}
\hline \multirow{2}{*}{ Feeds Used } & \multirow{2}{*}{ Water } & \multirow{2}{*}{ Ash } & \multirow{2}{*}{$\begin{array}{l}\text { Crude } \\
\text { Protein }\end{array}$} & \multicolumn{2}{|c|}{ Carbohydrates } & \multirow{2}{*}{ Fat } \\
\hline & & & & Fiber & N. F. E. & \\
\hline $1923^{*}$ & & & & & & \\
\hline Yellow Corn.......... & 9.65 & 1.50 & 9.07 & 2.13 & 73.78 & 3.87 \\
\hline White Corn...$\ldots \ldots \ldots \ldots \ldots \ldots$ & 10.41 & 1.41 & 9.60 & .1 .96 & 72.78 & 3.84 \\
\hline Wheat Middlings.............. & 10.90 & 4.21 & 16.59 & 5.60 & 57.60 & 5.10 \\
\hline Buckwheat Middlings............ & 9.47 & 5.26 & 32.03 & 4.63 & 40.10 & 8.51 \\
\hline Tankage. . . . . & 9.50 & 20.17 & 58.51 & 1.46 & 4.80 & 5.56 \\
\hline Yellow Corn................. & 11.42 & 1.31 & 8.54 & 2.10 & 72.67 & 3.94 \\
\hline White Corn...$\ldots \ldots \ldots \ldots \ldots$ & 10.78 & 1.78 & 8.33 & 2.28 & 73.22 & 3.61 \\
\hline Wheat Middlings............. & 8.68 & 3.97 & 15.96 & 7.06 & 59.01 & 5.32 \\
\hline Buckwheat Middlings........... & 10.84 & 3.74 & 21.93 & 4.42 & 53.56 & 5.51 \\
\hline Tankage..................... & 7.55 & 21.64 & 57.70 & 2.19 & 5.35 & 5.57 \\
\hline Yellow Corn................. & 12.58 & 1.29 & 11.18 & 2.38 & 69.45 & 3.12 \\
\hline White Corn.................. & 13.21 & 1.25 & 8.33 & 2.49 & 71.79 & 2.93 \\
\hline Wheat Middlings.............. & 11.01 & 4.91 & 16.66 & 9.18 & 53.18 & 5.06 \\
\hline Buckwheat Mid lings........... & 9.18 & 4.37 & 24.61 & 10.86 & 31.42 & 4.58 \\
\hline Tankage..................... & 7.71 & 21.60 & 59.36 & 1.20 & 2.33 & 7.80 \\
\hline $\begin{array}{l}\text { Fish Meal........................ } \\
\text { Henry and Morrison }\end{array}$ & 6.22 & 16.37 & 58.46 & 0.17 & 4.95 & 1383 \\
\hline Corn, Dent, Grade No. $2 \ldots \ldots \ldots$. & 14.8 & 1.4 & 9.6 & 1.9 & 67.6 & 4.8 \\
\hline Wheat Middlings (Stand.)....... & 10.5 & 4.4 & 17.4 & 6.0 & 56.8 & 4.9 \\
\hline Buckwheat Middlings........... & 12.0 & 4.8 & 28.3 & 4.8 & 42.7 & 7.4 \\
\hline Tankage $-60 \%$ percent. . . . . . . & 7.9 & 15.3 & 60.4 & 5.3 & 3.7 & 7.4 \\
\hline Fish Meal................ I & 10.5 & 28.1 & 51.4 & $\ldots \ldots \ldots$ & $\ldots \ldots \ldots$ & 8.3 \\
\hline
\end{tabular}

*Chemical analyses of the feeds used were made by chemists of the West Virginia Agricultural Experiment Station 
The pigs were fed twice each day, morning and evening. The liddlings and tankage (plus the mineral mixture for 1925) were fed $s$ a slop and then followed by the shelled corn, with the exception of ot IV in 1924 and 1925. The dry yeast, shelled corn, and middlings rere mixed together, thoroughly saturated, covered with water, and llowed to ferment from 36 to 48 hours before feeding. Three-range lectrical heaters were used to keep the mixture warm. The low heat vas used in mild weather, the medium in fairly cold weather, and he high in very cold weather. Each heater was placed in a fifty galon oil barrel containing water. The feed was mixed, put into large en gallon pails, and placed in the barrels, so that a warm water bath urrounded the pails containing the feeds' to be fermented. Three "rigs" of this lkind were required to keep properly fermented feed on hand. This apparatus proved valuable in keeping the feed mixtures it a warm temperature of between 80 and 100 degrees Fahrenheit at ill times.

The quantity of the rations fed was varied somewhat during the hree-year period. In 1923 and in 1925 the pigs were given 4 pounds of feed daily, per 100 pounds live weight, but in 1924 they were fed 5 pounds. The pigs' were weighed every 14 days, and the feed increased $n$ accordance with the lot weights. The yeast was fed at the rate of I pound per 100 pounds of corn and middlings.

\section{RESULTS}

Tables 2, 3, and 4 give the results of the feeding trials.

\section{Discussion of Results}

No attempt has been made to figure the cost of production in this work, as will be seen from the data given in Tables 2, 3, and 4 . Such costs are much more variable in a state like West Virginia, than they are in the corn belt states, which are close to the source of production of most hog feeds. The only explanation necessary in regard to the cost of the feeds used is, that the average price of buckwheat middlings for the three years was two dollars per ton more than wheat middlings. Farmers should apply their local feed prices, if they desire to calculate the cost of gains made on the various rations.

In 1923, white corn proved just as satisfactory as yellow corn, producing about the same daily gains and requiring almost exactly the same amount of feed to produce 100 pounds of pork. There were no indications that the pigs on the white corn ration were not as thrifty in every respect as those on yellow corn. In 1924 and 1925, when the pigs were fed for shorter periods (and in 1925 had a mineral 


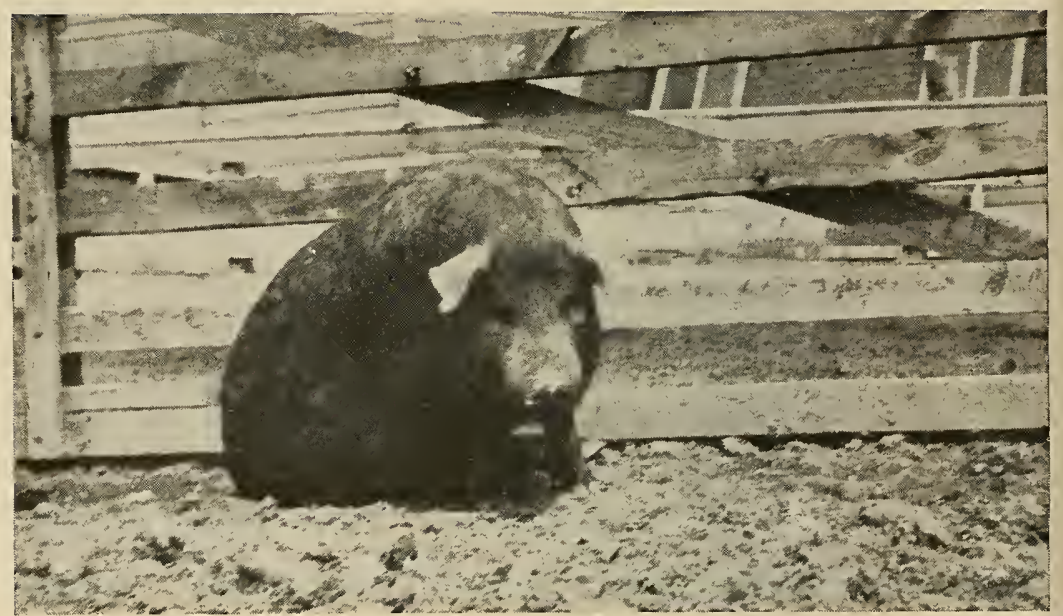

Fig. 2.-Duroc-Jersey pig (Lot III, 1924) after being given cod liver oll for a period of two weeks; still unable to rise without assistance.

TABLE 2.-Results of Feeding Trial, 1923, 98 Days, January 20 to April $28^{*}$

\begin{tabular}{|c|c|c|c|}
\hline \multirow{2}{*}{ ITEMS CONSIDERED } & \multicolumn{3}{|c|}{ LOTS } \\
\hline & I & II & III \\
\hline $\begin{array}{l}\text { Feed Mixture } \ldots \ldots \ldots \ldots \ldots \ldots \ldots \ldots \ldots \ldots \\
\text { Nutritive Ratio } \ldots \ldots \ldots \ldots \ldots \ldots \ldots \ldots \ldots\end{array}$ & $\begin{array}{l}\text { Yellow Corn } 300 \\
\text { Wheat Middlings } 100 \\
\text { Tankage } 20 \\
\qquad 1: 6.7\end{array}$ & $\begin{array}{l}\text { White Corn } 300 \\
\text { Wheat Middlings } 100 \\
\text { Tankage } 20 \\
1: 6.5\end{array}$ & $\begin{array}{l}\text { Yellow Corn } 300 \\
\text { Buekwheat Midd. } \\
\text { lings } 100 \\
\text { Tankage } 20 \\
1: 4.9\end{array}$ \\
\hline 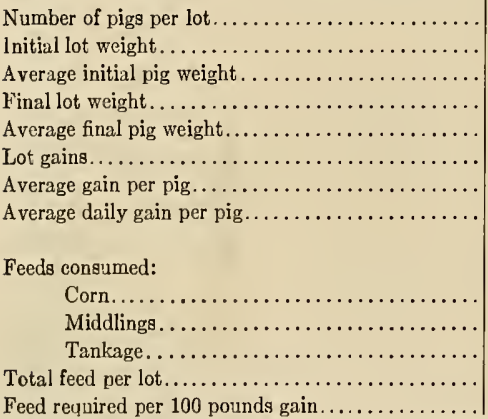 & $\begin{array}{r}9 \\
665.00 \\
73.88 \\
1485.00 \\
165.00 \\
820.00 \\
91.11 \\
0.93\end{array}$ & $\begin{array}{r}10 \\
722.00 \\
72.20 \\
1605.00 \\
160.50 \\
883.00 \\
88.30 \\
0.90\end{array}$ & $\begin{array}{r}9 \\
662.00 \\
72.55 \\
1729.00 \\
192.11 \\
1067.00 \\
118.55 \\
1.21\end{array}$ \\
\hline
\end{tabular}

*Feed mixtures and all weights are given in pounds. 
xture in addition). considerable trouble developed in the white eorn s. Both years abont the seventieth day, several hogs in all white m lots beeame wobbly and some went down, having every indication riekets.

'Three pigs in Lot II refused their feed on the seventieth day in 24. They walked in a wobbly manner, appeared weak of back, and following day went down and could not get up. These pigs were moved from the lot and fed a gruel containing cod liver oil. In two reks they were up staggering about, but still going down in their Ind legs oecasionally and exerting all their strength to rise again. May 2, these three pigs, still in a bad condition, were turned on alfa pasture (cod liver oil continued) and by June 16 two of them d apparently recovered. The other one, which never regained a rmal condition, was left with weak hind legs, a back earried too low, d a curved spine. (See Figures 2 and 3).

The seren remaining pigs in Lot II of the 1924 test seemed to do fly well from the seventieth to the eighty-fourth day, at which time were shipped to market. In a short drive of from fifty to seventyfe yards, necessary in order to load the pigs in wagons, several of im developed striking symptoms of the trouble shown by the other t:ee. No indieations of this eondition were shown by a single hog in her of the lots receiving yellow corn.

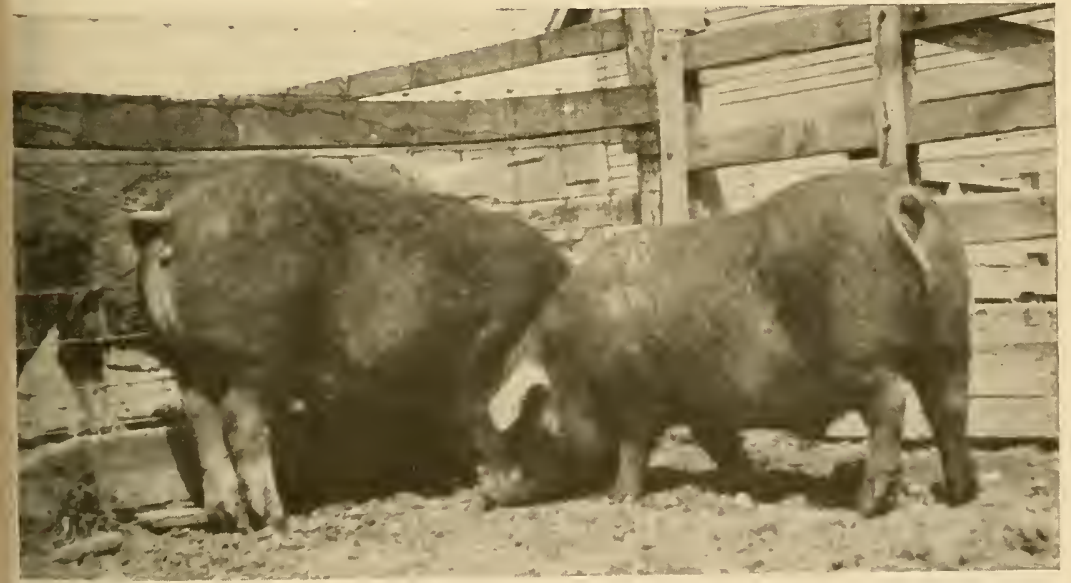

Fig. 3.-Two pigs (Lot III) which went down in 1924. This picture was en after they had been given cod liver oil and had been on alfalfa pasture 45 days. The pig at the left fully recovered but the other one did not. te the low curved condition of the back of the pig at the right, which is the se one shown in Figure 2. The picture in Figure 2 was taken before the pig is placed on alfalfa pasture. 


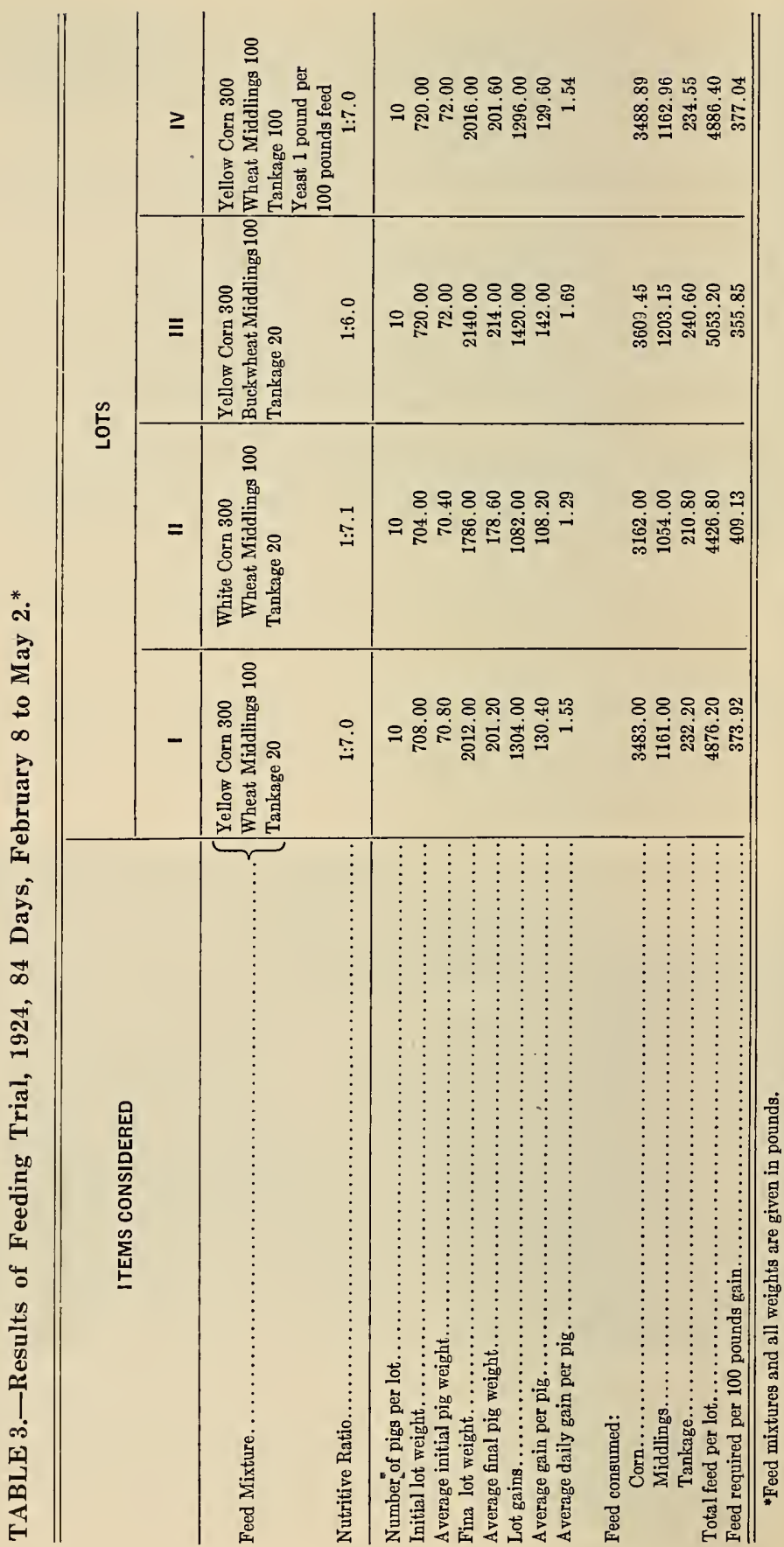




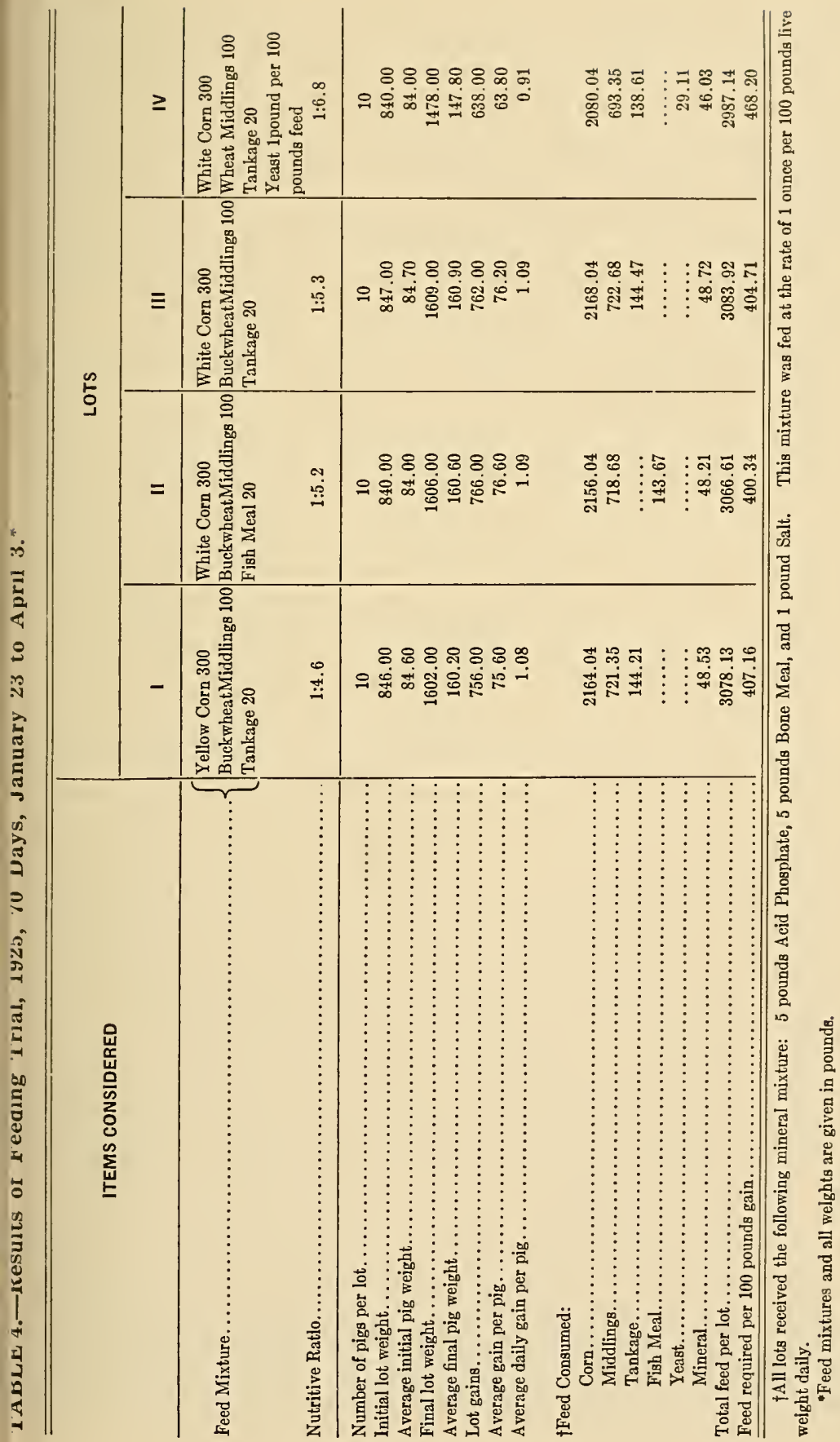


The data in T'able 3 show that Lot I (fed yellow corn, wb middlings, and tankage) made an average daily gain of 1.55 pou and required 373.92 pounds of feed to produce 100 pounds of $\mathrm{pc}$ while Lot II (fed white corn, wheat middlings, and tankage) made average daily gain of 1.29 pounds and required 409.13 pounds of $f$ to produce 100 pounds of pork. The data for Lot II include the th hogs which developed rickets and had been out of the lot for $14 \mathrm{~d}$ In other words, the hogs on white corn had made practically as nomical gains as those on yellow corn up to the seventy-day perioci which time the three hogs had to be removed from the lot.

At the beginning of the 1925 trial, each pig weighed approximat 14 pounds more than those at the start of the 1924 trial. The pig: the 1925 trial received a mineral mixture in addition to the gr ration, yet the same trouble which was experienced the preced year reoccurred. Three pigs in Lot II became wobbly and went feed in the sixty-fifth day of the trial, and on the seventieth day of these went down. On this date, two pigs in Lot III and three I in Lot IV were found to be staggering and practically unable to har themselves. Neither the buckwheat middlings, fish meal, nor the $\mathrm{n}$ eral mixture prevented the trouble which occurred in 1924.

The condition of the hogs in Lots II, III, and IV made it necess' to discontinue the trial on the seventieth day. Those pigs in these which were in a bad condition were segregated, and they, with all other pigs of these lots', were switched from white to yellow corn, given a small quantity of cod liver oil with each feeding, for thirtydays. All of the pigs improved and were in fairly good condition w shipped to market, which was thirty-five days after the bad effect the rations containing white corn were noticed. The yellow ch ration proved satisfactory again in 1925 in carrying pigs, weigh around 80 pounds at the start, to a marketable weight.

Figure 4 shows the growth curves on all lots for 1925. Notice white corn produced almost exactly the same gains as did yellow cin It will also be noted from the data in Table 4 that Lots I, II, and II made 100 pounds of gain on about the same amount of feed.

No satisfactory explanation can be given as to why the pig Lot II in 1923, did not show any signs of the trouble experiencecin all white corn lots in 1924 and 1925, however, several factors have contributed to this result. The pigs' were of practically the sil breeding each year and were handled in a similar manner up to time they were started on the feeding trials. 


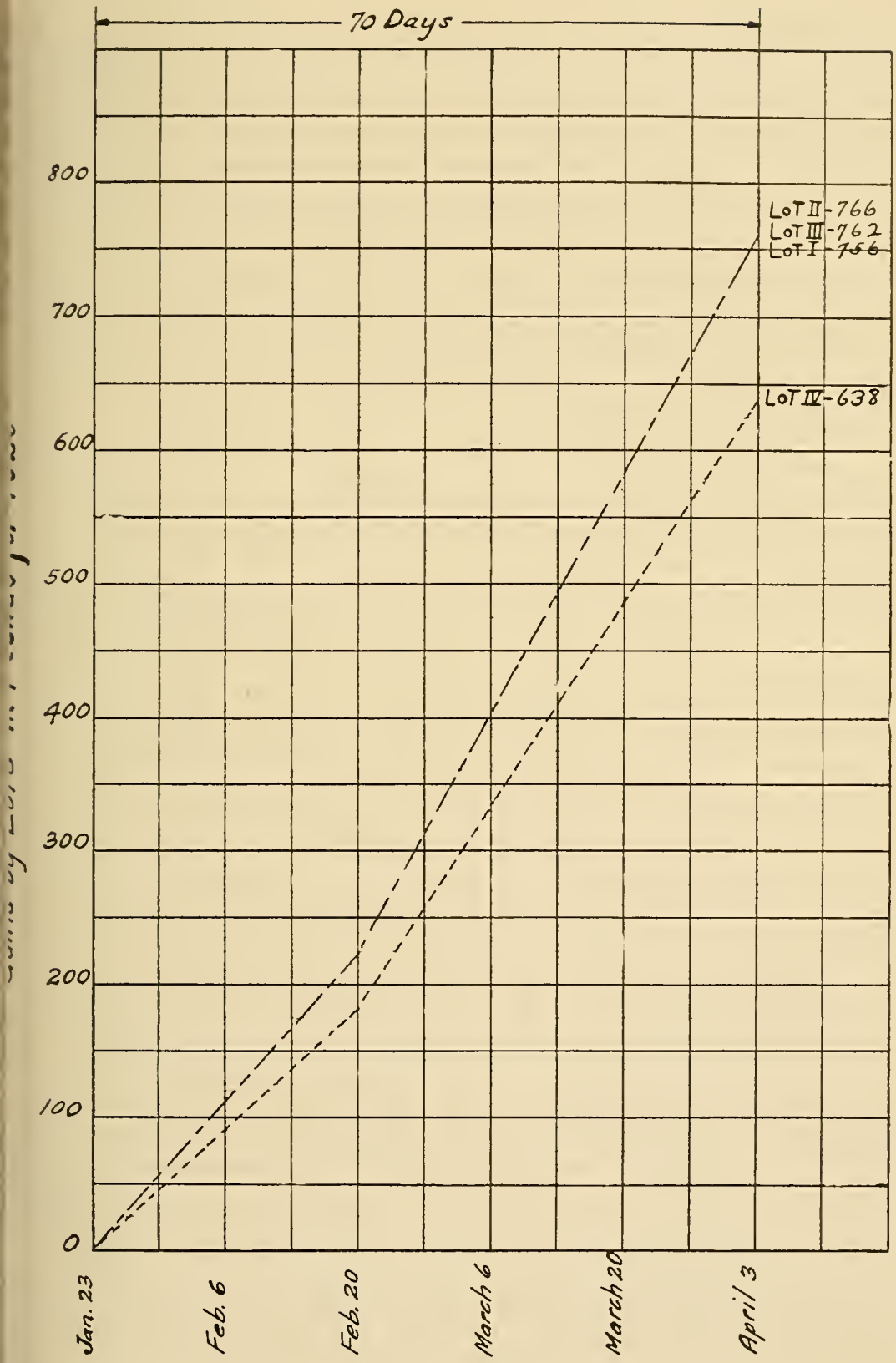

ig. 4-This graph illustrates the growth made by the four lots of pigs in 1925 trial. The growth made by Lots I. II, and III were so nearly equal each of the five fourteen-day weigh-periods that only one curve could be wn without confusion. 
In considering the feeding trials of 1923 and 1924, one might $\mathrm{g}$ as an explanation of the results obtained, the fact that a heavier rat was fed in 1924, which produced more rapid gains, thus causing pigs to go down at an earlier date. The fact, however, that pigs go down in Lot IV in 1925 on the same ration plus yeast in additi tends to discredit this assumption. Lot IV (1925) was fed at same rate per 100 pounds live weight as Lot II (1923) and it m: almost an identical rate of gain. Another explanation of this po might be found in comparing the amount of sunshine during the 1 : trial with that during the 1924 and 1925 trials. Data regarding th conditions are not available, however, and, hence, this factor can be offered as an explanation.

Since in these trials the white corn produced almost as good ga in 1923 and as good gains in 1924 and 1925 (up to 70 days) as yellow corn, the rachitic condition of the pigs fed white corn if hardly be attributed to a lack of vitamin A. The evidence tends 0 point to a lack of the anti-rachitic vitamin (vitamin $D$ ) in the wh corn rations, which vitamin is essential for pigs of the size used.

The experimental work of Hess and Unger (1) shows rather ct clusively that the cause of rickets in children is not associated with fat soluble vitamin, since, in many instances', the disease developed children being fed a diet containing an ample supply of this vitan Upon feeding babies, from five to nine months old, on a diet free fr the fat soluble vitamin, they were unable to cause the development $f$ rickets. McCollum (3) has shown that the ability of cod liver oil correct or prevent rickets is not vested in the fat-soluble vitamin, in a distinct vitamin-the anti-rachitic vitamin $D$.

Experimental evidence at the present time seems to indicate $t$ vitamin $\mathrm{D}$ may, or may not, be closely associated with vitamin $\mathrm{A}$.

Buckwheat middlings gave more rapid gains in weight than wh middlings, when both were fed in conjunction with yellow corn tankage, and reduced the amount of concentrates required to prod 100 pounds of gain (1923 and 1924). Buckwheat middlings seemed be superior to wheat middlings in the 1925 tests', when fed with wl corn and tankage, however, a portion of the ration containing wh middlings was fermented with yeast, as has been mentioned. In 19) Lot III made 100 pounds of gain on approximately 50 pounds less $f$ than Lot I, and in 1924 on approximately 18 pounds less. In 1C Lot III made 100 pounds gain on approximately 64 pounds less $\mathrm{f}$ than Lot IV. 
The fermentation (by use of the granular yeast) of the corn and ldlings in the ration fed Lot IV in 1924 did not improve it, so far the rate or economy of gain was concerned, but the pigs did show er coats of hair. No definite comparison can be made on the value yeast in 1925, as Lot IV was the only lot receiving wheat middlings the ration. The pigs of this lot earried smoother coats, however, in the pigs of the other three lots.

In the single trial of fish meal against tankage, the two feeds red about equal as protein supplements to corn and buckwheat Idlings. The rate of gain was equal for Lots II and III (Table 4), I the feed required to produce 100 pounds of gain was only 4.37 inds in favor of Lot II, which received fish meal.

\section{CONCLUSIONS}

1.- This study indicates that yellow corn is superior to white corn fattening pigs weighing from 70 to 80 pounds at the beginning of fattening period.

2.-Pigs weighing from 70 to 80 pounds make just as economical ins on white as on yellow corn for a certain period, which, in the 24 and 1925 trials, seemed to be about 70 days.

3.-The pigs fed white corn developed a rachitic condition (2 out 3 trials), while those fed the yellow corn did not.

4.-There is evidence that it was not the lack of the fat soluble amin in white corn, but the lack of the anti-rachitic vitamin (Vita$n \mathrm{D})$ which caused it to be inferior to yellow corn in these trials.

5.-Buckwheat middlings gave more rapid gains and required less ceentrates to produce 100 pounds gain than standard wheat midngs, when each was fed in conjunction with corn and tankage.

6.-Buckwheat middlings is not as uniform a product as wheat ddlings, consequently the purchaser should familiarize himself with 3 analysis of the product before giving it preference over wheat ddlings.

7.-Fish meal was approximately equal to tankage as a supplent to white corn, buckwheat middlings, and a mineral mixture (one al).

8.-The fermentation, for 36 to 48 hours, of corn and wheat ddlings by the use of 1 pound of powdered yeast to 100 pounds of ad, did not increase the rate of gains or the economy of gains. 
9.-If hogs are to be used for show purposes, yeast may have place in their feed since in these tests it resulted in an improved ce dition of the hair, which gave the pigs a sleeker appearance.

10.-Neither buckwheat middlings, fish meal, nor the mine: mixture used prevented the rachitic condition, since it occurred in white corn lots, in 1924 and 1925.

\section{BIBLIOGRAPHY}

(1) Hess, Alfred F., ANd Unger, Lester J.

1920. THE CHEMICAL ROLE OF THE FAT SOLUBLE VITAMIN: ITS RELAT To RICKETS. Jour. Amer. Med. Assoc. 74:217.

(2) Lamb, Alvin R., and Evvard, JoHn M.

1924. OBSERVATIONS OF THE VITAMIN A REQUIREMENTS OF SWINE. American Society of Animal Production, Record of Proceedings Annual Meeting, Dec. 1923. pp. 136-141.

(3) McCollum, E. V.

1923. PATHOLOGIC EFFECT OF LACK OF VITAMIN A AND OF ANTI-RACHJ vitamin. Jour. Amer. Med. Assoc. 81:894.

(4) MumFord, H. W.

1922-1923. ANNUAL RePORT, Ill. Agr. Expt. Sta. p. 16.

(5) RoBinson, W. L.

1921. SUPPLEMENTS to CORN FOR FAtTENing SWine. Ohio Agr. Ey Sta. Bul. 349, pp. 131-183.

(6) Russeld, H. L., ANd MORRison, F. B.

1920. NEW FARM FACTS. Director's Report, Wis. Agr. Expt. Sta. F 323, pp. 10-11.

(7) Russell, H. L., ANd Morrsion, F. B. 1922. NEW PAGES IN FARMING. Director's Report, Wis. Agr. Expt. Bul. 339, pp. 125-128.

(8) Steenbock, H. and Boutwell, P. W.

1920. THE COMPARATIVE NUTRITIVE VALUE OF WHITE AND YELLOW MAIZ Jour. Biol. Chem. 41:81-96.

(9) UNIVERSITY OF NEBRASKA.

1924. WHITE vs. YELLOW CORN. Report of Animal Husbandry Depe ment, University of Nebraska. Unpublished Data. 




\section{HECKMAN}

BINDERY INC.

\section{JUNE 99}

N. MANCHESTER \\ Bound-To-Please INDIANA 46962}


